\title{
Thinning Southern Pines - A Key to Greater Returns ${ }^{1}$
}

\section{Chris Demers, Michael Andreu, Babe McGowan, Alan Long, and Jarek Nowak ${ }^{2}$}

Many landowners plant pines with the intention of harvesting them at some point in the future. When pulpwood markets are favorable, a complete stand harvest within 15 to 20 years is possible and may bring an acceptable return. However, longer rotations can bring higher financial returns on larger diameter trees if landowners are willing to begin thinning their pine stands when trees are 10 to 15 years old. Pine sawtimber, poles and/or plylogs are most often the forest products with the highest value and, if economic returns are a priority, the most desirable products to come out of a timber stand. Thinning is a partial tree harvest in an immature stand to maintain or accelerate diameter growth of the remaining trees. If it is done properly, thinning can bring substantially higher revenues when trees are harvested at 25 to 40 or more years of age. Trees will respond to thinning best if they are thinned before 16 or 17 years of age.

The increased diameter growth after thinning results from the greater availability of light, water, and nutrients to the remaining trees. Ideally, the best and biggest trees should be retained to assure the most rapid increase in timber value. For best results, thinning should favor the tallest, best-formed trees over those that are overtopped, crooked, forked, diseased or otherwise undesirable. Timberland owners who wish to harvest high-value sawtimber-, plylogor pole-sized products at the end of the rotation should consider thinning a necessity.
For the landowner, thinning can bring

1. increased return on investment from the sale of highervalue forest products;

2. periodic income from the multiple harvests that lead to those higher-value forest products;

3. improved access for equipment, people and wildlife;

4. a healthy, vigorous forest with less risk of insect infestation, destructive fire, and wind damage; and

5. enhanced wildlife habitat with increased herbaceous ground cover

Before describing specific methods of thinning, we will review the underlying concepts of stand density, crown position and forest health. These will dictate if, when, and how to thin.

\section{Stand Density}

Stand density describes how much a site is being used by trees and how much the trees are competing with each other for the site's resources (water, light, nutrients, space). At high densities, the growth rates of individual trees slow down because there are more trees competing for the site's limited resources. Trees are usually thinned to achieve a particular density target.

\section{Measures of Density}

Trees per acre. In single-species, even-aged stands of known age, site quality, and history, the number of trees per

1. This document is SS FOR24, one of a series of the School of Forest Resources and Conservation, Florida Cooperative Extension Service, Institute of Food and Agricultural Sciences, University of Florida. First Published: March 2005. Reviewed December 2006 and April 2010. Revised July 2013. Please visit the EDIS website at http://edis.ifas.ufl.edu.

2. Chris Demers, forest stewardship coordinator, School of Forest Resources and Conservation, Michael Andreu, associate professor, School of Forest Resources and Conservation, Babe McGowan, consulting forester, McGowan Forestry Services, Alan Long, former professor, School of Forest Resources and Conservation, and Jarek Nowak, Florida Forest Service, Tallahassee, FL. 
acre is a useful measure of stand density. Typical densities in plantations range from 200 to 800 trees per acre.

Volume per acre. Because many management objectives relate to wood volume, it is often used as a measure of density. Stand volume is generally expressed as cubic feet (solid wood), board feet, or cords per acre. A cord is 128 cubic feet of stacked roundwood (whole or split, with or without bark) containing wood and airspace; an example of a cord is a stacked pile of firewood $4 \mathrm{ft}$ high $\mathrm{x} 4 \mathrm{ft}$ wide $\mathrm{x} 8 \mathrm{ft}$ long. Tons per acre is a weight measure that is derived from volume. Tons is the unit of measure most commonly used to buy or sell wood.

Basal Area. Basal area is a measure of stand density developed by foresters. It is the total cross-sectional area of tree stems in a stand, at breast height ( 4.5 feet above the ground), measured in square feet per acre. Basal area (BA) of a single tree in square feet is calculated using the formula:

$$
\mathrm{BA}=0.005454 \times \mathrm{x} \mathrm{d}^{2}
$$

Where: $\mathrm{d}=$ diameter (inches) of the tree at breast height (often abbreviated as "DBH").

\section{Tree Crown Position}

Thinning reduces stand density by targeting trees belonging to different tree crown classes. (Tree crown is composed of all the live branches of the tree.) Each tree class is described by the vertical crown position of its members relative to trees of lower or higher classes. Most planted pine stands have an even-aged structure, which means there is little or no difference in the age of the trees. However, as an evenaged stand grows, the trees compete for site resources and begin to differentiate in height and diameter. As the level of tree competition increases over time, individual tree growth slows down. This growth deceleration happens at different rates for different trees due to genetic, microsite and other differences. In the absence of thinning, the weakest and slowest-growing trees die and provide more room for larger and healthier neighbors. The variation in tree growth results in four distinct tree crown classes:

\section{Dominant trees:}

- crowns extend above the main tree canopy layer

- crowns receive full sunlight from above and the sides

- crowns are large and well-developed

- characterized by large diameters and exceptional tree vigor

\section{Codominant trees:}

- crowns form the main canopy layer

- receive sunlight from above but are restricted at the sides

- have medium-sized crowns and diameters

\section{Intermediate trees:}

- crowns reach only to the lower part of the main canopy

- receive sunlight from above only partially, if at all

- have small, crowded crowns and small diameters

\section{Overtopped (suppressed) trees:}

- crowns are entirely below the main canopy

- receive no direct sunlight

- are usually the smallest trees with poorly developed crowns

- show very low vigor

\section{Forest Health}

Forest health is the focus of forest management and the purpose of thinning. The primary purpose of thinning is to remove poorly performing trees and leave a healthy, vigorous stand. A healthy forest produces more tons of valuable timber per acre resulting in more tons of higher quality wood available to sell. The various insects and diseases that affect pine stands in the South have evolved to exploit unhealthy, stagnated, or damaged trees that are stressed. Healthy pine stands resist damage from insects, disease and wind. If done early in the pines' development, thinning is an important tool to prevent problems with insects, diseases, or other stresses such as wildlfire or strong winds.

\section{Fusiform Rust}

Fusiform rust is a native, fungus-caused disease that deforms and kills pines. Since the late 1950s, it has increased to epidemic proportions in slash and loblolly pine plantations throughout the South. This disease was first reported in the early 1900s and was neither widespread nor prevalent at that time. The spread of fusiform rust increased as the acreage of young, intensively managed pines increased across the South. The fungus causing fusiform rust is greatly favored in young, rapidly growing pine plantations of slash and loblolly pines, especially when established in high rust hazard areas and in close proximity to oaks, especially water oak, which are alternate hosts for the fungus. Oak abundance generally increases in areas where fire is absent. Most stems infected with fusiform rust disease should be removed in a thinning. Larger diameter stems with minor disease on branches can continue to have good growth rates and withstand high winds after thinning. If the stem infection rate of a stand exceeds 50\%, the best option may be to clearcut and regenerate with genetically improved, rust-resistant pines. However, if there are at least 150-200 healthy, well-formed trees per acre, removing the diseased trees and retaining the healthy ones 
is usually the best option. If there is an abundance of red oak species, especially water oak, in surrounding stands, they should be reduced if possible. A professional forester can help you make appropriate management decisions to minimize or deal with problems associated with fusiform rust. More information about this disease can be found at http://www.floridaforestservice.com/publications/fh_pdfs/ fusiform_rust_of_pines.pdf.

\section{Southern Pine Beetle}

Southern pine beetles (SPB) are native, aggressive insects that live predominantly in the inner bark of pine trees. Trees attacked by SPB often have hundreds of light-colored, dime-sized resin masses (i.e., pitch tubes) on the outer tree bark. SPB feed on living bark tissues where they construct winding, S-shaped galleries on the inside of the bark, which can effectively girdle and kill a tree. In addition, SPB carry and introduce blue-stain fungi into trees. These fungi colonize the water-conducting tissue and can block water flow within the tree. Once SPB have successfully colonized a tree, the tree generally will not survive, regardless of control measures. An important way to prevent SPB infestations in pine stands is to maintain high tree vigor. This can be achieved by thinning dense stands to a basal area of 80 sq. ft. per acre or less to reinvigorate tree growth. More information about SPB and its control can be found at http://edis.ifas.ufl.edu/IN333.

Cost-share assistance for thinning pine stands, prescribed fire and other treatments is available through the Florida Forest Service's Southern Pine Beetle Assistance and Prevention Program: http://www.floridaforestservice.com/ forest_management/fh_insects_spb_prevention_program. html

\section{Annosum Root Rot}

Loblolly and slash pine are particularly susceptible to this disease, which may be scattered through a stand or occur in pockets of dying or dead trees. Trees generally yellow and lose needles as they die from this disease, although they may just turn red in a short period of time. Dead trees gradually fall over from a loss of root support. Wind-blown fungus spores from nearby infection centers generally enter a stand by landing on freshly cut stumps or wounds during the colder months of the year. The stump and subsequent root infections spread to adjacent trees through root contact. The disease is most prevalent on well-drained sandy soils with higher $\mathrm{pH}$, such as those found on old agricultural fields. Prevention measures include prescribed burning during winter months before thinning to eliminate the spore-producing conks, thinning in high hazard areas during summer, and treating freshly cut stumps with borax immediately after thinning. More information about this disease is at: http://www.freshfromflorida.com/pi/enpp/ pathology/pathcirc/pp398.pdf

\section{When and How Much to Thin}

\section{Timing}

The first thinning should take place shortly after the crowns of the trees start to close (tree branches of neighboring trees begin to touch each other). This is when diameter growth will begin to decrease due to the trees' limited ability to capture sunlight, which is needed to produce the carbohydrates necessary for diameter and volume growth. An important indirect measure of a tree's ability to capture sunlight is live crown ratio. Live crown ratio is the percentage of a tree's height occupied by branches with green needles. In southern pines, optimum growth and vigor are maintained when the live crown makes up at least $40 \%$ of tree height (a live crown ratio of $40 \%$ or higher). Thinning is most beneficial for stand growth before the average live crown ratio falls below $40 \%$.

Another factor that influences thinning decisions is the marketability of the removed trees. The first commercial thinning should remove pulpwood-size trees and perhaps some chip-and-saw-size trees, if they are poorly formed or diseased. Pulpwood logs must be at least 10.5 feet long and 2-3 inches in diameter at the small end; some local markets require larger log sizes. To meet these minimum specifications, trees must be about 16 feet tall and have an average $\mathrm{DBH}$ of at least 5 inches before they are cut. It may be necessary to thin smaller trees if the average live crown ratio of the stand is below $40 \%$ and trees do not grow at least $5 \%$ in diameter per year. With the demand for woody biomass on the rise in some regions for energy production, these trees may have a market. Otherwise, "pre-commercially" thinned trees are usually left on the ground to decompose. In this case, thinning should be regarded as an investment in the quality of the stand for the future, when final harvest returns may justify the operation. See http://edis.ifas.ufl.edu/fr243 for information on precommercial thinning loblolly pine.

\section{Thinning Intensity}

The number of trees to remove depends on the initial stand density, site quality, and management objectives. For timber objectives, a thinning should reduce stand density to a level that maximizes individual tree growth without sacrificing full utility of the site. Density and stocking should be approached from the quality of the residual stand first; and 
second, the density of the residual stand. Depending on the site, the density and quality of the trees in the stand you are working with, and your management objectives, the residual basal area after the first thinning will usually fall between 45 to 85 square feet per acre of the very best trees capable of producing a higher-value product. These will be the healthiest, best-formed trees in the dominant and co-dominant crown classes. A suggested rule of thumb is to use basal area as a result, not a target. Basal area does not take into account the age of the stand, site productivity, and tree health and quality. Focus growth on the best trees in the stand and the basal area will follow.

Thinning, especially when followed by prescribed fire, can be great for wildlife habitat. Thinning allows more sunlight to reach the forest floor, encouraging the growth of herbaceous plants and shrubs, which provide food and cover for many upland wildlife species in the southeast. Subsequent thinnings and a prescribed fire regime during the rotation will promote an open tree canopy, diverse groundcover, and productive wildlife habitat. See http://edis.ifas.ufl. edu/uw132 for more information on the effects of fire on wildlife habitat.

\section{How to Thin}

Most producers use a combination of thinning methods to reach economic and/or wildlife habitat objectives. No matter which thinning method you choose, avoid thinning during times of drought or extreme wet weather to prevent damage to the site, and take care not to damage residual trees during logging. When trees do become damaged (frequently, for instance, the "bumper" or "turning" trees at the ends of thinned rows suffer some damage), they should be removed at the end of the logging operation. Landowners are encouraged to consult with or hire a professional forester to assist with thinning and other forest management activities. See http://edis.ifas.ufl.edu/fr125 for tips on selecting a consulting forester.

\section{Combine Row and Selection Thinning}

Although most discussions about thinning southern pines are about which rows to thin, the focus should be on what comes out of the remaining rows. Modern equipment, though large, is capable of taking out trees in the rows between cut rows, as in a $5^{\text {th }}$ or $7^{\text {th }}$ row thinning. Generally, the further apart the cut rows, the better. Think of the cut rows as access for the harvester to cut selected trees out of the remaining rows. It is best to remove trees based on selection thinning from fewer cut rows rather than taking out every 3rd or 4 th row. The first thinning is the most important thinning and sets the growth rate for the rest of the rotation. Properly executed thinnings consistently produce higher valued products, and thus more revenue. In addition to revenue goals, thinning greatly enhances wildlife habitat by providing light needed for important food plants to grow. Removing every $3^{\text {rd }}$ or $4^{\text {th }}$ row is essentially clearcutting $33 \%$ or $25 \%$ of the stand without regard to quality, and leaves only $66 \%$ or $75 \%$ of the stand to select from. Unless there is excessive disease or extreme variabity in density (see fusiform rust guidelines above), this should be avoided. Leaving the trees distributed over a larger portion of the stand can be much more profitable in the long term because you can select your best trees to grow into larger, more valuable products.

The premise for thinning is simply to take out the poor trees and leave the healthy crop trees for potential future harvest. Trees that are diseased, crooked, forked, suppressed or otherwise of poor quality or health should be removed in the first thinning. For best results, hire a professional forester to mark every thinning. If marking is not feasible for some reason, closely supervise each thinning, but especially the first, to ensure contractual guidelines are followed. Do not assume the logger or harvester operator will leave the trees most appropriate for the long-term health and productivity of the stand.

\section{Conclusion}

Thinning is an important silvicultural practice that redistributes the growth potential of the site to the best trees. Diameter growth rates are maintained or increased on residual trees after thinning, which increases the return on investment from higher-value trees. Biologically, thinning accelerates stand development by favoring the tallest, best-formed trees over those that are diseased, overtopped, crooked, forked, or otherwise undesirable and likely to die on their own if left in the stand long enough. In addition, thinning provides periodic income, improves access for equipment, recreation and hunting, and creates a generally healthier stand. Thinning is also beneficial for wildlife, especially when combined with prescribed fire or herbicide use to control competing vegetation. By allowing more light to reach the forest floor, thinning promotes growth of plants important as food and/or cover for wildlife species. Landowners are encouraged to consult with or hire a professional forester to assist with thinning and other forest management activities. 


\section{References}

Davis, L.S. and K. N. Johnson. 1987. Forest Management.

McGraw-Hill Publishing Co., NY. 790 pp.

Harrington, T. B. 2001. Silvicultural approaches for thin-

ning southern pines: method, intensity, and timing. Georgia

Forestry Commission, Publication \#FSP002. $17 \mathrm{p}$.

Harrington, T. B. 2001. Silvicultural basis for thinning southern pines: concepts and expected responses. Georgia Forestry Commission, Report \#FSP001. 13 p.

Meeker, J. R., W. N. Dixon, J. L. Foltz, and T. R. Fasulo. 2004. Southern Pine Beetle, Dendroctonus frontalis Zimmermann (Insecta: Coleoptera: Scolytidae). EENY-176 Entomology and Nematology Department, Cooperative Extension Service, Institute of Food and Agricultural Sciences, University of Florida. 6 pp.

Smith, D. M., B. C. Larson, M. J. Kelty, and P. M. Ashton. 1996. The Practice of Silviculture: Applied Forest Ecology, 9th ed. John Wiley and Sons, Inc. New York. 560 pp.

Schmidt, R. A. 1998. Rust Disease of Southern Pines: Biology, Ecology and Management. Bul. 903. School of Forest Resources and Conservation, University of Florida, Institute of Food and Agricultural Sciences, Gainesville. 8 pp.

Williston, H. L., W. E. Balmer, and D. Tomczak. 1998. Managing the Family Forest in the South. Management Bulletin R8-MB 1, USDA Forest Service. Atlanta. 92 p. 